\title{
PENDEKATAN INDUKTIF-DEDUKTIF DISERTAI STRATEGI THINK-PAIR-SQUARE-SHARE UNTUK MENINGKATKAN KEMAMPUAN PEMAHAMAN DAN BERPIKIR KRITIS SERTA DISPOSISI MATEMATIS SISWA SMA
}

\author{
Oleh: \\ Enung Sumaryati ${ }^{1}$ \\ Utari Sumarmo ${ }^{2)}$ \\ ${ }^{1}$ Guru SMA di Cimahi \\ ${ }^{2}$ STKIP Siliwangi Bandung, utari.sumarmo@yahoo.co.id
}

\begin{abstract}
Makalah ini melaporkan temuan satu eksperimen dengan disain tes awal-tes akhir dan kelompok kontrol yang dilaksanakan dengan mengimplementasikan pendekatan induktifdeduktif disertai dengan strategi Think-Pair-Square-Share untuk meningkatkan kemampuan pemahaman dan kemampuan berpikir krtis matematis siswa. Studi ini melibatkan 81 siswa kelas-11 dari satu SMA di Cimahi. Instrumen penelitian terdiri dari tes pemahaman matematis, tes berpikir kritis matematis dan skala pendapat. Studi menemukan bahwa pendekatan induktif-deduktif disertai dengan strategi Think-Pair-Square-Share lebih unggul dalam meningkatkan kemampuan pemahaman dan berpikir kritis matematis siswa daripada pembelajaran biasa. Kemampuan pemahaman dan kemampuan berpikir krtis matematis siswa yang mendapat pembelajaran dengan pendekatan induktif-deduktif disertai dengan strategi Think-Pair-Square-Share tergolong sedang dan kemampuan matematis siswa yang memperoleh pembelajaran biasa tergolong kurang. Namun ditemukan tidak terdapat perbedaan disposisi matematis pada kedua kelas, dan diposisi matematis tersebut tergolong sedang. Selain itu, studi juga menemukan terdapat asosiasi yang lemah antar kemampuan pemahaman, berpikir kritis, dan disposisi matematis. Namun siswa menunjukkan pendapat yang positif terhadap pembelajaran dengan pendekatan induktif-deduktif disertai strategi Think-Pair-Square-Share.
\end{abstract}

Kata Kunci : pendekatan induktif-deduktif, strategi Think-Pair-Square-Share, pemahaman matematis, berpikir kritis matematis, diposisi matematis

This paper presents the findings from a pretest-post test experimental control group design conducted by using inductive-deductive approach accompanied with Think-Pair-SquareShare strategy to investigate students' mathematical understanding and critical thinking abilities and students' disposition toward teaching approach. The study involved 81 grade11 students from a Senior High School in Cimahi. The instrumens were mathematical understanding and mathematical critical thinking abilities tests, and an opinion scale. The study found that inductive-deductive approach accompany with Think-Pair-Square-Share strategy was able to improve students' mathematical understanding and mathematical critical thinking abilities better than conventional teaching. Mathematical understanding and mathematical critical thinking abilities of students taught by inductive-deductive 
approach accompanied with Think-Pair-Square-Share strategy were classified as medium whereas those mathematical abilities of students taught by conventional approach were classified as low. However, there was no difference in mathematical disposition between students taught by inductive-deductive approach accompany with Think-Pair-Square-Share strategy and students taught by conventional teaching, and both mathematical disposition were classified as medium. The study also found that there were low association among mathematical understanding, critical thinking, and disposition. Moreover, the study found that students performed positive disposition toward inductive-deductive approach accompany with Think-Pair-Square-Share strategy.

Key words : inductive-deductive approach, Think-Pair-Square-Share strategy, mathematical understanding, critical mathematical thinking, disposition

\section{Pendahuluan}

Pada dasarnya, kemampuan pemahaman, berpikir kritis, dan diposisi matematis merupakan kemampuan dan diposisi esensial yang perlu dikembangkan pada dan dimiliki oleh siswa sekolah menengah (KTSP, 2006). Rasional pernyataan tersebut pada dasarnya tercermin dalam rumusan Tujuan Pembelajaran Matematika (KTSP, 2006) dan visi bidang studi matematika (Sumarmo, 2006, 2010). Tujuan Pembelajaran Matematika antara lain memuat kemampuan dan diposisi: memahami konsep matematika, menjelaskan keterkaitan antar konsep dan mengaplikasikan konsep atau algoritma, secara luwes, akurat, efisien, dan tepat dalam pemecahan masalah, serta memiliki sikap menghargai kegunaan matematika dalam kehidupan, yaitu memiliki rasa ingin tahu, perhatian, dan minat dalam mempelajari matematika, serta sikap ulet dan percaya diri dalam pemecahan masalah (KTSP, 2006). Demikian pula, pentingnya pemilikan kemampuan berpikir kritis matematis dan disposisi matematis terlukis dalam visi matematika yaitu: 1) mengarahkan pembelajaran matematika untuk pemahaman konsep dan idea matematika yang diperlukan untuk menyelesaikan masalah matematika dan ilmu pengetahuan lainnya; 2) pembelajran matematika ditujukan untuk mengembangkan kemampuan bernalar, berfikir sistimatik, kritis dan cermat, serta menumbuhkan rasa percaya diri, dan rasa keindahan terhadap keteraturan sifat matematika, dan mengembangkan sikap obyektif dan terbuka yang diperlukan dalam menghadapi masa depan yang selalu berubah. Sikap dan kebiasaan berfikir seperti di atas secara akumulatif menumbuhkan disposisi matematik (mathematical disposition) yaitu keinginan, kesadaran dan dedikasi yang kuat pada diri siswa untuk belajar matematika dan melaksanakan berbagai kegiatan matematika (Sumarmo, 2006, 2010).

Sumarmo (1987) dalam studi deskriptifnya menemukan kemampuan pemahaman matematis sejumlah siswa SMA di Jawa Barat masih rendah. Demikian pula, O'daffer dan Theonquist (Tata, 2009), serta Miller (Albania, 2010) melaporkan bahwa kemampuan berpikir kritis siswa sekolah menengah belum memuaskan dan 
mereka cenderung menghindar dari soal-soal yang tidak rutin. Namun beberapa studi lain, Albania (2010) dengan menerapkan pembelajaran kooperatif, Dahlan (2004) dengan menggunakan pembelajaran open-ended dan Lestari (2009) dengan mengimplementasikan pembelajaran kontekstual melaporkan bahwa kemampuan pemahaman matematis siswa lebih baik dari kemampuan siswa yang mendapat pembelajaran biasa. Studi lainnya, Ismaimuza (2010), Noer (2010), dan Runisah (2008) dengan menerapkan pembelajaran berbasis masalah, kemudian Mulyana (2008) dengan pembelajaran analitik sintetik, Rohaeti (2008) dengan pendekatan eksplorasi, dan Tata (2009) dengan menerapkan pembelajaran metakognitif melaporkan kemampuan berpikir kritis matematis siswa yang mendapat pembelajaran inovatif di atas lebih baik dari kemampuan siswa yang mendapat pembelajaran biasa.

Selain pendekatan-pendekatan inovatif di atas, terdapat pendekatan lain yaitu pendekatan induktif-deduktif dan strategi strategi Think-Pair-Square-Share yang juga memberi peluang siswa belajar aktif. Pembelajaran induktif-deduktif diawali dengan penyajian contoh-contoh, kemudian siswa mengidentifikasi, membedakan, menginterpretasi, menggeneralisasi dan akhirnya mengambil kesimpulan. Selanjtnya secara deduktif siswa memberikan contoh dari generalisasi. Taba (Joyce \& Weil; 2000) mengembangkan pendekatan induktif-deduktif berdasarkan tiga asumsi yaitu: proses berpikir dapat dipelajari, proses berpikir adalah suatu transaksi aktif antara individu dan data, mengembangkan proses berpikir sesuai dengan aturan. Implikasi dari pembelajaran ini adalah tumbuhnya semangat untuk menemukan, adanya kesadaran akan hakikat pengetahuan dan berkembangnya berpikir logis. Strategi Think-Pair-Square-Share merupakan satu bentuk belajar kooperatif di mana siswa melaksanakan belajar sendiri dan belajar dalam kelompok secara bersamaan. Strategi ini dirancang untuk meningkatkan kemampuan berpikir, komunikasi, dan mendorong siswa untuk berbagi informasi dengan siswa lain.

Beberapa studi (Amri, 2009, Dewanto, 2003) dengan menerapkan pembelajaran induktif-deduktif, dan studi Sabilulungan (2008) dan Setiadi (2010) yang mengimplementasikan strategi think-pair-square melaporkan bahwa siswa dan mahasiswa mencapai beragam kemampuan matematik yang lebih baik dari kemampuan matematis siswa yang mendapat pembelajaran biasa. Temuan di atas mengindikasikan bahwa pendekatan pembelajaran inovatif dan memberi peluang siswa lebih aktif belajar berhasil meningkatkan kemampuan pemahaman dan berpikir kritis matematik serta kemampuan matematis lainnya yang lebih baik dari pada pembelajaran biasa.

Memperhatikan pentingnya pemilikan kemampuan pemahaman dan berpikir kritis serta disposisi matematis pada siswa SMA, keunggulan pendekatan induktif dan deduktif dan strategi think-pair-square, serta temuan beberapa studi di atas, mendorong peneliti untuk melakukan studi menerapkan pembelajaran tadi untuk 
menganalisis pencapaian dan peningkatan kemampuan kemampuan pemahaman dan berpikir kritis matematis serta disposisi matematis siswa SMA.

\section{Telaah Kepustakaan}

\section{Pemahaman Matematis}

Secara umum indikator pemahaman matematik meliputi; mengenal, memahami dan menerapkan konsep, prosedur, prinsip dan idea matematika. Beberapa pakar antara lain Copeland, Polya, Pollatsek, dan Skemp (Sumarmo, 1987) menggolongkan pemahaman matematis pada tingkat rendah dan tingkat tinggi. Pemahaman matematis tingkat rendah misalnya: knowing how to (Copeland, dalam Sumarmo, 1987), pemahaman mekanikal dan pemahaman induktif (Polya, dalam Sumarmo, 1987), pemahaman komputasional (Pollatsek, dalam Sumarmo, 1987), pemahaman instrumental (Skemp, dalam Sumarmo, 1987) yang dicirikan dengan mengingat dan menerapkan rumus secara rutin dan menghitung secara sederhana, mengerjakan perhitungan secara algoritmik, hafal konsep dan prinsip tanpa kaitan dengan yang lainnya. Pemahamn matematis tingkat tinggi meliputi: knowing (Copeland, dalam Sumarmo, 1987), pemahaman rasional dan intuitif (Polya, dalam Sumarmo, 1987), pemahaman fungsional (Pollatsek, dalam Sumarmo, 1987), dan pemahaman relasional (Skemp, dalam Sumarmo, 1987) yang dicirikan dengan kegiatan: menghitung secara sadar, membuktikan kebenaran suatu rumus dan teorema, memperikirakan kebenaran dengan pasti, mengkaitkan satu konsep/prinsip dengan konsep dan atau prinsip lainnya.

Merujuk pada taksonomi Bloom, Sumarmo (1987) mengidentifikasi kemampuan pemahaman matematis dalam tiga jenis perilaku kognitif yaitu mengubah dari satu bentuk matematis ke bentuk matematis lain, menginterpretasi suatu konsep, prinsip, dan ekspresi matematis, dan mengintrapolasi dan mengekstrapolasi suatu kecenderungan data. Dalam tujuan pembelajaran matematika (KTSP, 2006) kemampuan pemahaman matematis meliputi: memahami konsep matematika, menjelaskan keterkaitan antar konsep dan mengaplikasikan konsep atau algoritma, secara luwes, akurat, efisien, dan tepat dalam memecahkan masalah.

Sebagai contoh, tentukan gradien garis singgung di titik $\mathrm{A}(1,-3)$ dan di titik $\mathrm{B}(3$, 3) terhadap fungsi $f(x)=x^{2}-4 x$. Tugas ini tergolong pemahaman tingkat rendah (knowing how to, pemahaman komputasional, mekanikal, instrumental) karena langsung menghitung $\mathrm{f}^{\prime}(1)$ dan $\mathrm{f}^{\prime}(3)$. Jika pertanyaan dilanjutkan dengan: bagaimana kedudukan kedua garis tersebut, maka tugas tersebut tergolong tingkat tinggi (knowing, pemahaman rasional, fungsional, relasional) karena menghubungkan satu konsep dengan konsep lain yaitu konsep, sifat, kesejajaran atau tegak lurus. 


\section{Berpikir Kritis Matematis}

Berpikir kritis adalah perwujudan perilaku belajar yang berkaitan dengan pemecahan masalah. Pada umumnya siswa yang berpikir kritis akan menggunakan prinsip-prinsip dan konsep-konsep dasar dalam menjawab pertanyaan 'bagaimana' dan 'mengapa'. Dalam hal ini siswa dituntut menggunakan strategi kognitif tertentu yang tepat untuk menguji kedalaman gagasan pemecahan masalah dan mengatasi kesalahan atau kekurangan (Reber dalam Syah, 2003). Glaser (Sumarmo, 2010) menyatakan bahwa berpikir kritis matematis memuat kemampuan dan disposisi yang dikombinasikan dengan pengetahuan, kemampuan penalaran matematika, dan strategi kognitif yang sebelumnya untuk menggeneralisasikan, membuktikan, mengases situasi matematik secara reflektif.

Model berpikir kritis yang direkomendasikan oleh O'Daffer dan Thornquist (Suryadi, 2005) meliputi tahapan-tahapan: memahami masalah, melakukan pengkajian terhadap bukti, data, asumsi; menyatakan dan mendukung suatu kesimpulan, keputusan, atau solusi; menerapkan kesimpulan, keputusan, atau solusi. Menurut Ennis (Noer, 2010), pemikir kritis memiliki beberapa keterampilan dan disposisi. Keterampilan berpikir kritis meliputi: mengidentifikasi fokus, menganalisis argumen, mengajukan pertanyaan atau memberikan klarifikasi, mendefinisikan pernyataan, mempertimbangkan kualitas dari definisi, mengidentifikasi asumsi-asumsi yang tidak dinyatakan, mempertimbangkan kredibilitas sumber, mengobservasi dan mempertimbangkan kualitas observasi, melakukan deduksi, induksi, membuat dan menilai pertimbangan.

Sebagai contoh, pertanyaan: periksa dan berikan penjelasan apakah garis g yang menyinggung kurva $y=x^{2}+2$ melalui titik berabsis $\frac{1}{2}$. Contoh lain misalnya: "Samakah kurva $\mathrm{y}=x^{2}$ dengan daerah defnisi $\{\mathrm{x} \mid \mathrm{x}$ bilangan real $\}$ dengan kurva $\mathrm{y}=$ $x^{2}$ dengan daerah defnisi $\{\mathrm{x} \mid \mathrm{x}$ bilangan bulat $\}$ ? Tugas-tugas di atas tergolong tugas berpikir kritis memberikan klarifikasi terhadap suatu kasus. Andaikan diberikan fungsi f dengan aturan $\mathrm{f}(\mathrm{x})=x^{3}$. Asumsi apa yang berlaku dalam persamaan fungsi tersebut? Tugas tersebut adalah tugas mengidentifikasi asumsi suatu pernyataan.

\section{Disposisi Matematis}

Pada dasarnya, dalam pembelajaran matematika pengembangan kemampuan dalam ranah kognitif dan perilaku dalam ranah afektif dilaksankan secara bersamaan waktu. Dalam KTSP (2006), tujuan dalam ranah afektif antara lain: memiliki sikap menghargai kegunaan matematika dalam kehidupan, yaitu memiliki rasa ingin tahu, perhatian, dan minat dalam mempelajari matematika, serta sikap ulet dan percaya diri dalam pemecahan masalah. Tujuan tersebut juga terlukis dalam visi bidang studi matematika yaitu: 1) mengarahkan pembelajaran matematika untuk pemahaman konsep dan idea matematika yang diperlukan untuk menyelesaikan masalah matematika dan ilmu pengetahuan lainnya; 2) mengarahkan pembelajaran 
matematika untuk mengembangkan kemampuan bernalar, berfikir sistimatik, kritis dan cermat, serta menumbuhkan rasa percaya diri, dan rasa keindahan terhadap keteraturan sifat matematika, dan mengembangkan sikap obyektif dan terbuka yang diperlukan dalam menghadapi masa depan yang selalu berubah. Dalam pembelajaran matematika kebiasaan berpikir dan berperilaku seperti di atas tumbuh secara bertahap membentuk perilaku yang dinamakan disposisi matematik yaitu keinginan, kesadaran dan dedikasi yang kuat pada diri siswa untuk belajar matematika dan melaksanakan berbagai kegiatan matematika (Sumarmo, 2010).

NCTM (1989) mendefiniskan disposisi matematis sebagai kecenderungan untuk berpikir dan bertindak dengan cara yang positif. Kecenderungan ini tercermin oleh ketertarikan siswa dan kepercayaan diri dalam mengerjakan matematika, kemauan untuk mengeksplorasi dan ketekunan dalam memecahkan masalah matematika, serta kemauan untuk merefleksikan pemikiran mereka sendiri, ketika mereka belajar matematika. Polking (Sumarmo, 2010) merinci indikator disposisi matematik yang meliputi: 1) rasa percaya diri dalam menggunakan matematika, memecahkan masalah, memberi alasan dan mengkomunikasikan gagasan, 2) fleksibilitas dalam menyelidiki gagasan matematik dan berusaha mencari metoda alternatif dalam memecahkan masalah; 3) tekun mengerjakan tugas matematik; 4) minat, rasa ingin tahu, dan daya-temu dalam melakukan tugas matematik; 5) cenderung memonitor, merepleksikan performansi dan penalaran mereka sendiri; 6) mengaplikasikan matematika ke situasi lain dalam matematika dan pengalaman sehari-hari; 7) mengapresiasi peran matematika dalam kultur dan nilai, matematika sebagai alat dan sebagai bahasa.

\section{Pendekatan Induktif-deduktif dan Strategi Think-Pair-Square-Share}

Model pembelajaran induktif-deduktif adalah model pembelajaran yang memadukan model pembelajaran induktif dengan model pembelajaran deduktif. Model pembelajaran induktif-deduktif diawali dengan contoh-contoh yang ditujuan supaya siswa mengidentifikasi, membedakan, kemudian menginterpretasi, menggeneralisasi dan akhirnya mengambil kesimpulan. Kemudian secara deduktif siswa dapat memberikan contoh dari generalisasi.

Model pembelajaran induktif dipelopori oleh Taba (Joyce \& Weil; 2000) dan didesain untuk meningkatkan kemampuan berpikir. Taba membangun model ini dengan pendekatan yang didasarkan atas tiga asumsi sebagai berikut.

1) Proses berpikir dapat dipelajari. Mengajar seperti yang disarankan oleh Taba berarti membantu siswa mengembangkan kemampuan berpikir induktif melalui latihan (practice).

2) Proses berpikir adalah suatu transaksi aktif antara individu dan data. Ini berarti bahwa siswa menyampaikan sejumlah data dari beberapa domain pelajaran. Siswa menyusun data ke dalam sistem konseptual, menghubungkan poin-poin data dengan data yang lain, membuat generalisasi dari hubungan yang mereka 
temukan, dan membuat kesimpulan dengan hipotesis, meramalkan dan menjelaskan fenomena.

3) Mengembangkan proses berpikir dengan urutan yang "sah menurut aturan". Postulat Taba bahwa untuk menguasai keterampilan berpikir tertentu, pertama seseorang harus menguasai satu keterampilan tertentu sebelumnya, dan urutan ini tidak bisa dibalik.

Joyce, Weil dan Calhoun (Aunurrahman, 2009) mengemukakan beberapa strategi berpikir induktif yang sekaligus juga menggambarkan langkah-langkah pengembangan kemampuan berpikir induktif; Strategi pertama adalah pembentukan konsep, meliputi tahap perhitungan dan pendaftaran, tahap pengelompokkan dan pemberian label atau kategorisasi. Strategi kedua, interpretasi data yang meliputi tahap mengidentifikasi hubungan antara data atau masalah, tahap menemukan hubungan, dan tahap membuat inferensi. Strategi ketiga, aplikasi prinsip yang meliputi tahap memprediksi konsekuensi, menjelaskan fenomena-fenomena dan menguji hipotesis.

Dampak pengiring dari pembelajaran induktif menurut Joyce dkk (2000) mencakup: "Semangat untuk menemukan; adanya kesadaran akan hakikat pengetahuan; dan berpikir logis". Pembelajarannya mencakup langkah-langkah: penyajian informasi, konsep-konsep, keterampilan dan membentuk hipotesis; proses pembentukan konsep; konsep-konsep, sistem konseptual dan aplikasinya". Soedjadi (Mulyana, 2008) mengemukakan bahwa penyajian matematika perlu dimulai dari contohcontoh, yaitu hal-hal yang khusus, selanjutnya secara bertahap menuju kepada pembentukan suatu kesimpulan yang bersifat umum. Kesimpulan itu dapat berupa definisi atau teorema.

Strategi Think-Pair-Square-Share merupakan salah satu strategi yang memberi kesempatan pada siswa untuk bekerja sendiri serta bekerja sama dengan orang lain dan bertujuan untuk meningkatkan kemampuan berpikir, komunikasi, dan mendorong siswa untuk berbagi informasi dengan siswa lain. Suherman, dkk (2003) mengemukakan beberapa keunggulan pembelajaran kooperatif antara lain: membantu para siswa meningkatkan sikap positif siswa dalam matematika, sangat bermanfaat bagi para siswa yang heterogen, menonjolkan interaksi dalam kelompok, membuat siswa menerima siswa lain yang berkemampuan dan berlatarbelakang yang berbeda". Dengan belajar secara berkelompok, memungkinkan siswa lebih berani untuk mengemukakan ide-idenya, lebih berpartisipasi dalam belajar, sehingga mengurangi rasa cemas terhadap matematika.

Grinham (2009) menjelaskan dalam strategi think-pair-square-share: 1) Pada think siswa memiliki periode waktu untuk merenung dan merumuskan pikirannya tentang topik atau pertanyaan yang diberikan; 2) Pada tahap pair, siswa bekerja berpasangan dan mendiskusikan pikiran masing-masing dan mendengarkan pikiran teman lainnya; 3) Pada tahap square, siswa bekerja dalam kelompok empat dan membahas 
setiap pikiran teman lain lagi, mengarah pada kesepakatan yang mencerminkan pendapat akhir kelompok; 4) Pada tahap share, beberapa kelompok square ditunjuk untuk melaporkan kesepakatan, kemudian menyusun kesepakatan baru yang mencerminkan semua kelompok.

\section{Penelitian Yang Relevan}

Sumarmo (1987) dalam studi deskriptifnya terhadap 414 siswa SMA kelas 11 dari beberapa kota di Jawa Barat menemukan kemampuan pemahaman matematis siswa yang tergolong belum memuaskan. Dalam studi ini tes pemahaman matematis diadopsi dan dimodifikasi dari tes dalam Second International Mathematics Study (SIMS) dan disesuaikan dengan kondisi siswa di Indonesia. Demikian pula Wahyudin (1999) dalam studi deskriptifnya menemukan kemampuan pemahaman matematis siswa masih rendah. Namun beberapa penelitian (Albania, 2010, Dahlan, 2004, Lestari, 2009) melaporkan keunggulan beberapa pendekatan pembelajaran pembelajaran inovatif dibandingkan dengan pembelajaran biasa. Dahlan, (2004) yang mengimplementasikan pembelajaran open-ended, Lestari (2009) yang menerapkan pembelajaran kontekstual, dan Albania (2010) yang melaksanakan pembelajaran kooperatif berbantuan komputer ketiganya terhadap siswa SMP melaporkan bahwa pembelajaran inovatif tersebut menghasilkan kemampuan pemahaman matematis siswa yang lebih baik dibandingkan dengan hasil dari pembelajaran biasa.

Demikian pula, O'daffer dan Theonquist (Tata, 2009), serta Miller (Albania, 2010) melaporkan bahwa kemampuan berpikir kritis siswa sekolah menengah belum memuaskan dan mereka cenderung menghindar dari soal-soal yang tidak rutin. Namun beberapa studi lain, Albania (2010) dengan menerapkan pembelajaran kooperatif, Studi lainnya, Ismaimuza (2010), Noer (2010), dan Runisah (2008) dengan menerapkan pembelajaran berbasis masalah, kemudian Mulyana (2008) dengan pembelajaran analitik sintetik, Rohaeti (2008) dengan pendekatan eksplorasi, dan Tata (2009) dengan menerapkan pembelajaran metakognitif melaporkan kemampuan berpikir kritis siswa yang mendapat pembelajaran inovatif di atas lebih baik dari kemampuan siswa yang mendapat pembelajaran biasa.

Dua studi Amri (2009) dan Dewanto, (2003) menerapkan pembelajaran induktifdeduktif, dan dua studi Sabilulungan (2008) dan Setiadi (2010) mengimplementasikan strategi think-pair-square melaporkan bahwa siswa dan mahasiswa mencapai beragam kemampuan matematik yang lebih baik dari kemampuan matematis siswa yang mendapat pembelajaran biasa. Penelitian Dewanto (2003) melaporkan bahwa pembelajaran dengan pendekatan induktifdeduktif meningkatkan kemampuan berpikir matematik tingkat tinggi matematika mahasiswa dan mahasiswa menunjukkan sikap positif terhadap pembelajaran tersebut. Penelitian Sabilulungan (2008) menemukan bahwa pembelajaran kooperatif dengan teknik think-pair-square, berhasil meningkatkan kemampuan 
penalaran dan komunikasi matematis siswa SMP daripada pembelajaran biasa. Dalam studi Amri (2009) ditemukan bahwa kemampuan siswa dalam mengilustrasikan ide-ide matematik pada kelas yang mendapat pembelajaran induktif-deduktif secara umum lebih baik dibandingkan dengan kemampuan siswa yang mendapat pembelajaran konvensional. Demikian pula, Setiadi (2010) melaporkan bahwa kemampuan pemahaman dan komunikasi matematis siswa SMP melalui pembelajaran kooperatif dengan teknik think-pair-square meningkat lebih baik dibandingkan dengan peningkatan kemampuan matematis tadi siswa yang memperoleh pembelajaran biasa.

Temuan-temuan di atas mengindikasikan bahwa pendekatan pembelajaran inovatif dan memberi peluang siswa lebih aktif belajar berhasil meningkatkan pemahaman dan berpikir kritis matematis dan kemampuan matematis lainnya yang lebih baik dari pada pembelajaran biasa.

\section{Metode Penelitian}

Penelitian ini merupakan studi eksperimen dengan Pre-test Post-test Control Group Design dengan memberikan perlakuan pembelajaran induktif-deduktif disertai dengan strategi Think-Pair-Square-Share dan bertujuan menelaah peningkatan kemampuan pemahaman dan berpikir matematis siswa. Subyek sampel penelitian ini adalah 81siswa kelas XI IPA yang berasal dari satu SMA di Cimahi. Instrumen penelitian ini adalah tes pemahaman matematis, tes berpikir matematis, skala diposisi matematis, dan skala pendapat terhadap pembelajaran induktif-deduktif disertai dengan strategi Think-Pair-Square-Share.

Berikut ini disajikan contoh butir tes pemahaman matematis, butir tes berpikir kritis matematis, dan butir-butir skala disposisi matematis dalam studi ini.

Contoh butir tes pemahaman matematis

1. Diberikan fungsi $f(x)=x^{2}-4 x$.

a) Gambarlah sketsa grafik fungsi $f$

b) Gambarlah garis singgung di titik $\mathrm{A}(1,-3)$ dan di titik $\mathrm{B}(3,-3)$. Bagaimana kedudukan dua garis singgung tersebut?

c) Tentukan gradien garis singgung di titik A dan di titik B!

d) Tentukan persamaan garis singgung di titik A dan di titik B!

2. Tentukan persamaan garis singgung kurva $y=\frac{1}{3} x^{3}+x^{2}$ yang tegak lurus pada garis dengan persamaan $x-y+3=0$. Jelaskan konsep atau aturan yang mendasari penyelesaian soal tersebut! 
Contoh butir tes berpikir kritis matematis.

1. Periksa apakah turunan pertama fungsi $f(x)=2 \cos ^{3}(1-2 x)$ adalah $f^{\prime}(x)=6 \sin (2-4 x) \cos (1-2 x)$ ? Berikan penjelasan!

2. Apakah garis $g$ yang menyinggung kurva $y=x^{2}+2$ di titik yang berabsis $\frac{1}{2}$, dan garis $h$ yang menyinggung kurva $y=x^{2}+1$ di titik yang berabsis $\frac{1}{2}$ masingmasing membentuk sudut $60^{\circ}$ dengan sumbu X ? Apa alasannya? Bagaimana kedudukan antara garis $g$ dan garis $h$ tersebut? Jelaskan!

3. Contoh butir skala disposisi matematik

Keterangan Ss Sering sekali Kd: Kadang-kadang

Sr Sering Jr: Jarang Jrs : Jarang sekali

\begin{tabular}{|c|l|c|c|c|c|c|}
\hline No. & \multicolumn{1}{|c|}{ Kegiatan dan pendapat } & Ss & Sr & Kd & Jr & Js \\
\hline 1. & $\begin{array}{l}\text { Berani mengemukakan gagasan di depan } \\
\text { teman lain }\end{array}$ & & & & & \\
\hline 2. & Merasa cemas mengerjakan tes matematika & & & & & \\
\hline 3. & $\begin{array}{l}\text { Menawarkan cara lain dalam menyelesaikan } \\
\text { soal matematika }\end{array}$ & & & & & \\
\hline 4. & $\begin{array}{l}\text { Merasa takut mengemukakan alasan atas } \\
\text { jawaban yang diperoleh }\end{array}$ & & & & & \\
\hline 5. & $\begin{array}{l}\text { Cepat menyerah mengerjakan soal } \\
\text { matematika yang sulit }\end{array}$ & & & & & \\
\hline 6. & $\begin{array}{l}\text { Menerima cara penyelesaian teman yang } \\
\text { berbeda }\end{array}$ & & & & & \\
\hline 7. & $\begin{array}{l}\text { Merasa tertantang mengerjakan soal } \\
\text { matematika yang rumit }\end{array}$ & & & & & \\
\hline
\end{tabular}

\section{Hasil Penelitian dan Pembahasan}

Temuan mengenai kemampuan pemahaman, berpikir kritis, dan disposisi matematis studi ini disajikan pada Tabel 1. Analisis terhadap data pada Tabel 1, menghasilkan bahwa pretes kemampuan pemahaman dan kemampuan berikir kritis siswa pada kedua kelas pembelajaran tidak berbeda dan tergolong sangat rendah yaitu 7,2\% dan $6,1 \%$ dari skor ideal tes pemahaman matematis dan 9,36\% dan 10,1\% dari skor ideal tes berpikir kritis. Setelah pembelajaran kemampuan pemahaman dan kemampuan berpikir kritis siswa yang mendapat pembelajaran induktif-deduktif disertai strategi Think-Pair-Square-Share (berturut-turut 53,4\% dan 44,4\%, dengan gain 0,50 dan $0,39)$ meningkat lebih baik dari kemampuan siswa yang mendapat pembelajaran biasa (berturut-turut 39,9\% dan 32,8\% dengan gain 0,36 dan 0,25). Namun demikian pencapaian kemampuan pemahaman dan kemampuan berpikir kritis matematis siswa pada kedua kelas pembelajaran masih tergolong belum memuaskan. Temuan tersebut menunjukkan bahwa tugas pemahaman relasional matematis dan tugas 
berpikir kritis matematis dalam topik kalkulus masih sulit bagi siswa kelas XI SMA. Kondisi tersebut dapat dipahami karena topik kalkulus yang diajarkan adalah tentang turunan fungsi yang tergolong sukar dan berkenaan dengan proses matematis yang tidak sederhana yaitu pemahaman matematis tingkat tinggi dan berpikir kritis yang tidak mudah untuk siswa.

Tabel 1

Rerata Kemampuan Pemahaman, Berpikir Kritis, dan Disposisi Matematis Siswa pada Kelas Pendekatan Induktif-Deduktif- TPSS dan Kelas Biasa

\begin{tabular}{|c|c|c|c|c|c|c|c|c|c|c|}
\hline \multirow{3}{*}{$\begin{array}{l}\text { Kemampuan } \\
\text { dan disposisi } \\
\text { matematis }\end{array}$} & \multicolumn{5}{|c|}{$\begin{array}{c}\text { Pendekatan Induktif-Deduktif } \\
\text { Disertai Strategi TPSS }\end{array}$} & \multicolumn{5}{|c|}{ Pembelajaran Biasa } \\
\hline & \multicolumn{2}{|c|}{ Pretes } & \multicolumn{2}{|c|}{ Postes } & \multirow{2}{*}{$\begin{array}{c}\text { Gain } \\
\bar{x}\end{array}$} & \multicolumn{2}{|c|}{ Pretes } & \multicolumn{2}{|c|}{ Postes } & Gain \\
\hline & $\overline{\bar{x}}$ & $\%$ & $\bar{x}$ & $\%$ & & $\overline{\bar{x}}$ & $\%$ & $\overline{\bar{x}}$ & $\%$ & $\bar{x}$ \\
\hline $\begin{array}{r}\text { Pemahaman } \\
\text { Matematis } \\
\end{array}$ & 2,88 & 7,2 & 21,34 & 53,4 & $\begin{array}{c}0,50 \\
\text { (sedang) }\end{array}$ & 2,43 & 6,1 & 15,95 & 39,9 & $\begin{array}{c}0,36 \\
\text { (sedang) }\end{array}$ \\
\hline $\begin{array}{c}\text { Berpikir } \\
\text { Kritis } \\
\text { Matematis } \\
\end{array}$ & 2,34 & 9,36 & 11,10 & 44,4 & $\begin{array}{c}0,39 \\
\text { (sedang) }\end{array}$ & 2,52 & 10,1 & 8,22 & 32,8 & $\begin{array}{c}0,25 \\
\text { (rendah) }\end{array}$ \\
\hline $\begin{array}{l}\text { Disposisi } \\
\text { Matematis }\end{array}$ & & & 102,05 & & & & & 104,55 & & \\
\hline
\end{tabular}

Catatan: Skor ideal tes pemahaman : 40;

Skor ideal disposisi matematis: 175

Disposisi matematis dalam studi ini diukur dengan skala disposisi model Likert dalam bentuk kegiatan dan pendapat positif dan negatif antara lain: rasa percaya diri, fleksibilitas, dan memonitor diri dalam melaksanakan proses berpikir matematis dengan lima (5) pilihan sangat sering (SS), sering SR), kadang-kadang (KD), jarang (JR), dan jarang sekali (JS). Ditemukan tidak terdapat perbedaan diposisi matematis siswa pada kedua kelas pembelajaran dan keduanya tergolong sedang atau netral (102,05 dan 104,55 dari skor ideal 175). Temuan tersebut menunjukkan bahwa kedua pembelajaran belum optimal meningkatkan aspek afektif disposisi matematis berkenaan dengan pemahaman dan berpikir kritis matematis.

Dihubungkan dengan capaian kemampuan pemahaman dan berpikir kritis matematis yang masih tergolong kurang (antara 32,8 dan 53,4\% dari skor ideal), terdapat kesesuaian dengan temuan capaian disposisi matematis (102,05 dan 104,55 dari skor ideal 175) yang tergolong sedang atau netral. Beberapa kegiatan dan pendapat terhadap proses-proses matematis yang tergolong belum memuaskan antara lain adalah dalam hal rasa percaya diri, sifat fleksibel, rasa ingin tahu, dan mengaplikasikan matematika ke bidang lain. Sedang diposisi yang tergolong sudah cukup baik adalah mengenai kegiatan memonitor diri dan mengapresiasi matematika (Lihat Tabel 2). 
Tabel 2

Skor Disposisi Matematis berdasarkan Komponennya

\begin{tabular}{|l|c|c|}
\hline \multicolumn{1}{|c|}{ Indikator } & \multicolumn{2}{c|}{ Rata-rata Skor siswa } \\
\cline { 2 - 3 } & $\begin{array}{c}\text { Pembelajaran } \\
\text { TPSS I-D }\end{array}$ & $\begin{array}{c}\text { Pembelajaran } \\
\text { Biasa }\end{array}$ \\
\hline $\begin{array}{l}\text { Rasa percaya diri dalam menggunakan matematika, } \\
\text { memecahkan masalah, memberi alasan dan } \\
\text { mengomunikasikan gagasan }\end{array}$ & 2,75 & 2,67 \\
\hline $\begin{array}{l}\text { Fleksibel dalam menyelidiki gagasan matematika } \\
\text { dalam berusaha mencari metoda alternatif dalam } \\
\text { memecahkan masalah }\end{array}$ & 2,87 & 2,96 \\
\hline $\begin{array}{l}\text { Minat, rasa ingin tahu dan daya temu dalam melakukan } \\
\text { tugas matematika }\end{array}$ & 2,85 & 2,92 \\
\hline Memonitor diri sendiri & 3,24 & 3,37 \\
\hline $\begin{array}{l}\text { Mengaplikasikan matematika ke situasi lain dalam } \\
\text { matematika dan masalah sehari-hari }\end{array}$ & 2,78 & 2,83 \\
\hline $\begin{array}{l}\text { Mengapresiasi peran matematika dalam kultur dan } \\
\text { nilai, matematika sebagai alat dan bahasa }\end{array}$ & 3,12 & 3,35 \\
\hline
\end{tabular}

Keterangan: skor netral: 3

Dihubungkan dengan capaian kemampuan pemahaman dan berpikir kritis matematis yang masih tergolong kurang (antara 32,8 dan 53,4\% dari skor ideal), terdapat kesesuaian dengan temuan capaian disposisi matematis (102,05 dan 104,55 dari skor ideal 175) yang tergolong sedang atau netral. Beberapa kegiatan dan pendapat terhadap proses-proses matematis yang tergolong belum memuaskan antara lain adalah dalam hal rasa percaya diri, sifat fleksibel, rasa ingin tahu, dan mengaplikasikan matematika ke bidang lain. Sedang diposisi yang tergolong sudah cukup baik adalah mengenai kegiatan memonitor diri dan mengapresiasi matematika (Lihat Tabel 2).

Analisis selanjutnya menghasilkan derajat asosiasi (C) yang rendah antara kemampuan pemahaman dan berpikir kritis matematis, antara kemampuan pemahaman dan disposisi matematis dan antara kemampuan berpikir kritis dan diposisi matematis yaitu berturut-turut: $\mathrm{C}=0,23, \mathrm{C}=0,56$, dan $\mathrm{C}=0,15$. Pada Tabel 3 tidak terdapat klasifikasi kemampuan berpikir kitis matematis yang tinggi dan kemampuan pemahaman yang sedang terdistribusi pada kemampuan berpikir kritis matematis yang sedang dan rendah. 
Tabel 3

Asosiasi Kemampuan Pemahaman dan Berpikir Kritis Matematis

\begin{tabular}{|c|c|c|c|c|}
\hline \multirow{2}{*}{$\begin{array}{c}\text { Pemahaman } \\
\text { Matematis }\end{array}$} & \multicolumn{3}{|c|}{ Berpikir Kritis Matematis } & \multirow{2}{*}{ Total } \\
\cline { 2 - 4 } & Tinggi & Sedang & Rendah & \\
\hline Tinggi & 0 & 9 & 6 & 15 \\
\hline Sedang & 0 & 24 & 31 & 55 \\
\hline Rendah & 0 & 2 & 9 & 11 \\
\hline Total & 0 & 35 & 46 & 81 \\
\hline
\end{tabular}

Tabel 4

Asosiasi Kemampuan Pemahaman dan Disposisi Matematis

\begin{tabular}{|c|c|c|c|c|}
\hline \multirow{2}{*}{$\begin{array}{c}\text { Pemahaman } \\
\text { Matematis }\end{array}$} & \multicolumn{3}{|c|}{ Disposisi Matematis } & \multirow{2}{*}{ Total } \\
\cline { 2 - 4 } & Tinggi & Sedang & Rendah & \\
\hline Tinggi & 0 & 15 & 0 & 15 \\
\hline Sedang & 2 & 51 & 2 & 55 \\
\hline Rendah & 0 & 4 & 7 & 11 \\
\hline Total & 2 & 70 & 9 & 81 \\
\hline
\end{tabular}

Pada Tabel 4 dan Tabel 5, disposisi matematis siswa lebih mengumpul pada klasifikasi sedang, namun terdistribusi pada kemampuan pemahaman dan kemampuan berpikir kritis matematis yang sedang dan rendah. 
Tabel 5

Asosiasi Kemampuan Berpikir Kritis Matematis dan Disposisi matematis

\begin{tabular}{|c|c|c|c|c|}
\hline \multirow{2}{*}{$\begin{array}{c}\text { Disposisi } \\
\text { Matematis }\end{array}$} & \multicolumn{3}{|c|}{ Berpikir Kritis Matematis } & \multirow{2}{*}{ Total } \\
\cline { 2 - 4 } & Tinggi & Sedang & Rendah & \\
\hline Tinggi & 0 & 1 & 1 & 2 \\
\hline Sedang & 0 & 32 & 38 & 70 \\
\hline Rendah & 0 & 2 & 7 & 9 \\
\hline Total & 0 & 35 & 46 & 81 \\
\hline
\end{tabular}

Berbeda dengan temuan mengenai diposisi matematis, temuan mengenai pendapat siswa terhadap pembelajaran induktif-deduktif disertai strategi Think-Pair-SquareShare siswa menunjukkan pendapat yang cukup positif (Tabel 6), khususnya terhadap pembelajaran berkelompok dan pembelajaran induktif-deduktif. Namun pendapat siswa terhadap tugas berpikir kritis matematis cenderung masih netral.

Selain temuan-temuan yang belum cukup memuaskan, dari kuesioner diperoleh kesan pendapat siswa yang agak jenuh dengan belajar melalui Lembar Kerja Siswa (LKS) yang terus-menerus selama pembelajaran. Siswa berkeinginan bahwa belajar melalui LKS perlu diselingi dengan pembelajaran yang tatap muka, diskusi, dan penjelasan dari guru. Temuan tersebut menggambarkan bahwa peran guru dalam pembelajaran tidak sepenuhnya dapat tergantikan oleh penjelasan tertulis melalui LKS.

\section{Tabel 6}

Pendapat Siswa terhadap Pembelajaran Induktif-deduktif disertai Strategi Think-Pair-Square-Share

\begin{tabular}{|l|c|}
\hline \multicolumn{1}{|c|}{ Aspek } & Skor siswa \\
\hline $\begin{array}{l}\text { Pandangan siswa terhadap pembelajaran dengan cara } \\
\text { berkelompok }\end{array}$ & 2,87 \\
\hline Pandangan siswa terhadap penyajian LKS & 2,6 \\
\hline $\begin{array}{l}\text { Pandangan siswa terhadap pendekatan pembelajaran induktif- } \\
\text { deduktif }\end{array}$ & 2,62 \\
\hline Pandangan siswa terhadap soal-soal berpikir kritis & 2,52 \\
\hline
\end{tabular}

Keterangan: Skor netral 2,5 


\section{Kesimpulan dan Saran}

Berdasarkan hasil analisis data dan temuan penelitian yang telah dikemukakan sebelumnya, diperoleh kesimpulan sebagai berikut.

Peningkatan dan pencapaian kemampuan pemahaman matematis siswa yang mendapat pendekatan induktif-deduktif disertai dengan strategi think-pair-squareshare dan lebih baik dibandingkan dengan kemampuan pemahaman matematis siswa yang mendapat pembelajaran biasa. Peningkatan dan pencapaian kemampuan pemahaman matematis yang diperoleh itu berada pada kategori sedang.

Peningkatan dan pencapaian kemampuan berpikir kritis matematis siswa yang mendapat pendekatan induktif-deduktif disertai dengan strategi think-pair-squareshare lebih baik dibandingkan dengan siswa yang mendapat pembelajaran biasa. Peningkatan kemampuan berpikir kritis siswa berada pada kategori sedang, sedangkan pencapaiannya masih berada pada kategori rendah.

Tidak terdapat perbedaan disposisi matematis antara siswa yang mendapat pendekatan induktif-deduktif disertai dengan strategi think-pair-square-share dan siswa yang mendapat pembelajaran biasa. Disposisi matematis siswa tersebut berada pada kategori netral. Disposisi matematis siswa cenderung mengumpul pada klasifikasi sedang dan sangat sedikit jumlah siswa dengan disposisi matematis tinggi atau rendah.

Terdapat asosiasi rendah antara kemampuan pemahaman dan berpikir kritis matematis, antara kemampuan pemahaman dan disposisi matematis dan antara kemampuan berpikir kritis dan disposisi. Kondisi ini menunjukkan bahwa saling pengaruh antara pencapaian kemampuan matematis dan pemilikan disposisi matematis tergolong lemah. Diposisi matematis siswa mengumpul pada katagori sedang dan terdistribusi pada kemampuan pemahaman dan berpikir matematis sedang dan rendah. Siswa menunjukkan pendapat cukup positif terhadap pendekatan induktif-deduktif disertai dengan strategi think-pair-square-share, namun siswa merasa agak jenuh dengan pemberian LKS yang terus menerus selama pembelajaran.

Berdasarkan temuan dan pembahasan berikut ini diajukan saran sebagai berikut. Berhubung materi penelitian ini yaitu tentang turunan fungsi tergolong sukar, untuk memperoleh hasil yang lebih baik dalam LKS pembelajaran dengan pendekatan induktif-deduktif disertai dengan strategi think-pair-square-share dan dalam pembelajaran biasa disarankan disajikan cukup banyak latihan beragam mulai dari sederhana sampai ke yang pemahaman tingkat tinggi dan berpikir kritis. Kemudian untuk menghindarkan perasaan jenuh pada siswa dalam belajar melalui LKS yang terus menerus, pembelajaran hendaknya diselingi pertemuan tatap muka, diskusi kelas, penjelasan, bimbingan, dan scaffolding dari guru. 


\section{DAFTAR PUSTAKA}

Albania, I.N. (2010). Menulis Matematika Menggunakan Sistem Aljabar Komputer dengan Setting Kooperatif untuk Meningkatkan Kecerdasan Emosional dan Pemahaman Matematis. Tesis pada PPS UPI. Bandung: tidak diterbitkan.

Amri. (2009). Peningkatan Kemampuan Representasi Matematik Siswa SMP melalui Pembelajaran dengan Pendekatan Induktif-Deduktif. Tesis pada PPS UPI. Bandung: tidak diterbitkan.

Aunurrahman. (2009). Belajar dan Pembelajaran. Bandung: Alfabeta.

Dahlan, J.A. (2004). Meningkatkan Kemampuan Penalaran dan Pemahaman Matematik Siswa Sekolah Lanjutan Tingkat Pertama melalui Pendekatan Open-Ended. Disertasi pada PPS UPI. Bandung: tidak diterbitkan.

Dewanto, S.P. (2003). Upaya Meningkatkan Kemampuan Berpikir Tingkat Tinggi melalui Pembelajaran dengan Menggunakan Pendekatan Induktif-Deduktif. Tesis pada PPS UPI. Bandung: tidak diterbitkan.

Grinham, G. (2009). Think-Pair-Square-Share. [online]. Tersedia: http://www.slideshare.net/ greg4758/think-pair-square-share [14 Pebruari 2012].

Joyce, B. and Weil, M. dan Calhoun, E. (2000).Models of Teaching. [Eighth Edition].Sydney:Pearson.

Mulyana, T. (2008). Pembelajaran Analitik Sintetik untuk Meningkatkan Kemampuan Berpikir Kritis dan Kreatif Matematik Siswa Sekolah Menengah Atas. Disertasi pada PPS UPI: tidak diterbitkan.

NCTM. (1989). Curriculum and Evaluation Standards for School Mathematics. Reston, VA: NCTM.

Noer, S.H. (2010). Peningkatan Kemampuan Berpikir Kritis, Kreatif, dan Reflektif (K2R) Matematis Siswa SMP melalui Pembelajaran Berbasis Masalah. Disertasi pada PPS UPI: tidak diterbitkan.

Rohaeti, E.E. (2008). Pembelajaran dengan Pendekatan Eksplorasi untuk Mengembangkan Kemampuan Berpikir Kritis dan Kreatif matematika Siswa Sekolah Menengah Pertama. Disertasi pada PPS UPI: tidak diterbitkan.

Sabilulungan, A. (2008). Pembelajaran Kooperatif dengan Teknik Think-Pair-Square (TPS) untuk Meningkatkan Kemampuan Penalaran dan Komunikasi Matematis Siswa SMP. Tesis. UPI Bandung: Tidak diterbitkan.

Setiadi, Y. (2010). Meningkatkan Kemampuan Pemahaman dan Komunikasi Matematis Siswa SMP melalui Pembelajaran Kooperatif dengan Teknik Think-Pair-Square. Tesis. UPI Bandung: Tidak diterbitkan.

Suherman, E. dkk (2003). Strategi Pembelajaran Matematika Kontemporer.

Bandung: JICA FPMIPA UPI. 
Sumarmo, U. (1987). Kemampuan Pemahaman dan Penalaran Matematika Siswa SMA Dikaitkan dengan Kemampuan Penalaran Logik Siswa dan Beberapa Unsur Pembelajaran. Disertasi pada PPS UPI. Bandung: tidak diterbitkan.

(2000). Pengembangan Model Pembelajaran Matematika untuk Meningkatkan Kemampuan Intelektual Tingkat Tinggi Siswa Sekolah Dasar. Laporan Hibah Bersaing Tahap I, Tahap II, dan Tahap III: tidak diterbitkan.

(2006). Berpikir Matematika Tingkat Tinggi: Apa, mengapa, dan bagaimana dikembangkan pada siswa sekolah menengah dan mahasiswa calon guru. Makalah pada seminar Pendidikan Matematika di Jurusan Matematika FMIPA UNPAD.

(2010). Berpikir dan Disposisi Matematik: Apa, Mengapa, dan Bagaimana Dikembangkan pada Peserta Didik. [Online]. Tersedia: http://www.docstoc.com/docs/ 62326333/Pembelajaran-Matematika. $\quad[5$ Maret 2012].

Runisah. (2008). Penggunaan SC3R dalam Pembelajaran Matematika untuk Meningkatkan Kemampuan Berpikir Kritis Matematis Siswa SMA. Tesis pada PPS UPI: tidak diterbitkan.

Suryadi, D. (2005). Penggunaan Pendekatan Pembelajaran Tidak Langsung serta Pendekatan Gabungan Langsung dan Tidak Langsung dalam Rangka Meningkatkan Kemampuan Berpikir Matematika Tingkat Tinggi Siswa SLTP. Disertasi. PPS UPI Bandung: Tidak diterbitkan.

Tata. (2009). Meningkatkan Kemampuan Berpikir kritis Siswa Melalui Pembelajaran Metakognitif Berorientasi Teori Van Hiele. Tesis pada PPS UPI Bandung: tidak diterbitkan. 